\title{
Impact of Human Capital Input and Institutional Factors on Productivity of Female Staff in Princess Nourah bint Abdulrahman University (PNU)
}

Hiyam Ahmed Abdulrahman*

Department of Economics, Princess Nourah bint Abdulrahman University, Saudi Arabia

\begin{abstract}
This study discusses the impact of human capital input and institutional factors on female staff productivity of Princess Norah University (PNU) in Saudi Arabia. A descriptive analysis model (Achieve) was used, consisting of seven individual and institutional factors. One sample T-Test, regression and correlation analysis tools were used. Main findings of the study were: Ability factor had the highest impact on PNU female staff productivity. Environment, Incentive, Validity and Evaluation factors had limited effect on female productivity in PNU. To boost the female staff productivity, the study recommended that more investment on human capital is required, promoting the work environment, developing the evaluation and incentive systems providing strong support for female staff by the university administration.
\end{abstract}

Keywords: Human capital; Productivity; Institutional factors

\section{Introduction}

Human resources are considered as the main production factor for any organization, the productivity of Labour is affected by many factors. Some are personal referred to the Labour's ability to perform the job tasks in an efficient way. These individual factors are called human capital factors or input, such as education, experience, knowledge and soft skills. Other factors influencing the productivity of Labour are relevant to the work system and regulations of the organization, known as institutional factors.

This study discusses the productivity of female staff in one of the largest female higher education institutions worldwide, Princess Norah Bint Abdul Rahman University (PNU) in Kingdom of Saudi Arabia with a capacity of about 60,000 female students. The staffs of the university are mainly female with very few male employees. The productivity of female staff in this University affects significantly the total performance and output of the university.

\section{Questions of the study}

The main question of the study is represented in:

What is the impact of human capital inputs and institutional factors on the productivity of female staff of PNU? And what are the best ways to improve female staff productivity?

\section{Objectives of the study}

This study aims to:

- Illustrate the definition and measurements of Labour productivity

- Explain the determinants of productivity, particularly Labour productivity

- Describe and analyse the impact of productivity's determinants on PNU female staff

- Suggest methods for improving female productivity in Saudi Arabia in general and for PNU female staff in particular.

\section{Contribution of the study}

According to Saudi Arabia goal to develop national human capital and expanding female participation in the Labour-force as it is stated in (Saudi Vision 2030), scientific research in this field becomes important, particularly with the scarcity of studies presented about female productivity in Saudi Arabia. This study contributes in reflecting the human capital and institutional factors affecting female productivity in PNU from staff view as a model for female productivity in KSA.

\section{Hypothesis}

- Education, technical and soft skills, experience and training has positive correlation with PNU female productivity.

- Existence of clear strict regulations of the university, affect positively the PNU female productivity.

- Work Environment is the most effective factor for female staff productivity in PNU.

- Incentive system practiced in PNU affect positively the female staff productivity.

- There is low significance of organizational support (Help) and authorities validity on PNU female staff productivity.

- Evaluation system has low effect on PNU female staff productivity.

\section{Concepts and Literature Review}

Human capital is a relatively modern term used to express the human accumulation of knowledge, skills and experience on a macro level for a nation or as an input (Labour) for the organization on a micro level. In the early 1990s decade, development of human capital became one of the strategic goals for many countries. Saranac [1] indicated that the key to sustaining a profitable company or a healthy economy is the productivity of the workforce, our human capital. Human capital

*Corresponding author: Abdulrahman HA, Department of Economics, Princess Nourah bint Abdulrahman University, Saudi Arabia, Tel: + 96611822 0000; E-mail: Hiyamrahim@yahoo.com

Received October 12, 2017; Accepted November 01, 2017; Published November 08, 2017

Citation: Abdulrahman HA (2017) Impact of Human Capital Input and Institutional Factors on Productivity of Female Staff in Princess Nourah bint Abdulrahman University (PNU). Bus Eco J 8: 324. doi: 10.4172/2151-6219.1000324

Copyright: (c) 2017 Abdulrahman HA. This is an open-access article distributed under the terms of the Creative Commons Attribution License, which permits unrestricted use, distribution, and reproduction in any medium, provided the original author and source are credited. 
has prominent role in modern growth theory; endogenous growth models suggest that human capital may generate economic growth in the long term [2]. Remarkably contribution of human capital in the economic development led economies and organizations to give more emphasis for improving human capital through imposing policies and presenting strategic plans and programs to achieve development goals. The design, formulation, and implementation of HRD strategies can create a robust multi-level platform conducive for national growth and prosperity for countries in general [3]. As a consequence of this compilation productivity growth and productivity levels are common [4]. Moreover, productivity is the foundation for increasing income and economic welfare for nations. Recent development in economic growth theory showed important role of commercial openness in human capital, research and development, foreign direct investment and other factors for enhancing growth and productivity in the long run [5].

Productivity is an indicator to show the ability of production factors to achieve a level of output measured to inputs used in production process. It means to achieve the required goals through transferring inputs into outputs in the form of commodities or services with least cost, that to get the highest quality of output from given inputs [6]. International Labour Organization [7] defines productivity as a relation between output and production factors, it occurs when there is increase in output accompanied by relative less increase in inputs, or when the same output is produced by less inputs.

On other hand, Productivity is divided into partial and total productivity; Partial productivity is the relation between output and one of the production factors. Total productivity is the relation between inputs and all production factors. Total factor productivity (TFP) covers different production inputs or factors, and thus enables the identification of distinct contributions of Labour, capital, intermediate consumption and technology/efficiency to the final product. TFP measures productivity more comprehensively; however, it is also more difficult to calculate. Broadly, productivity measures can be classified as single factor productivity measures (relating a measure of output to a single measure of input) or multifactor productivity measures (relating a measure of output to a bundle of inputs) [8].

However, Labour productivity is a sort of partial productivity; it reflects the contribution of human capital in the production process. It means the quantity of production obtained per unit of Labour, which can be represented either by: number of hours worked, or by the number of employed persons. It is considered one of the fundamental factors for any economy to attain scientific and industrial progress and ultimately economic development, and it is the main factor for increasing or decreasing of living standards. In this sense, Economic policy therefore tries to create favourable framework conditions for efficient utilization of Labour factor [9]

Labour productivity is affected by many factors, some are individual and others are institutional. It depends on the availability and quality of Labour resources and applied technologies. As a result, it influences the production process and costs. Ziapour [10] indicated that a single factor can't account for the development of Labour force, but a combination of different factors interfere with promotion of Labour productivity. To analyze productivity, the organization has to diagnosing gaps, strengths and weakness, and then work to promote productivity. Some tools are used to evaluate productivity such as; value added, productivity ratio and productivity standards. Main sources for promoting productivity are; Increasing capital accumulation, Reallocation of resources, Improving Labour education and skills, Development of knowledge, Changes in investment and human climate, Polices and regulations of work, Abundance of good infrastructure (electricity, transportation, communication.....), Work environment (temperature, light, comfortable environment), Ways for performing job tasks, Training of employees, Administrative system, Encouraging system, Job description and evaluation and finally, Desire for work (work stability and safety, good relation, fair wages, financial encouragement, occupation comfortably, respectability).

The above mentioned factors are factors of productivity in general, and for Labour productivity in particular. Labour productivity is affected by all those factors with different levels. Ability is an individual factor reflects the human input; it is represented in the skills, education, training, experience and attitude of the worker to perform his job duties. Ability difference may be the true source of wage differentials. In theory, education is the main human capital input, more able person gets more from education, it increases workers' productivity and this increase in productivity raises wages [11]. Similarly, training is considered important factor for social change resulted from improving productivity on individual, organizational and social levels [7]. Most workers augment their human capital stock through on job training; general and specific [11].

Similarly, Job satisfaction is a fundamental factor for directing the productivity of Labour in an organization. It is a general attitude towards one's job, the difference between the amount of rewards workers receive and the amount they believe they should receive [6]. The regulation system, wage structure, evaluation process, validity limits and incentive system are all organizational factors which have disparate effect on Labour productivity. According to the Wages Theory, wages is considered the main factor for increasing the productivity of Labour. There are positive correlation between wages and productivity; increase in productivity is accompanied with increase in wages of Labour. Labour compensations are determined in the long run by value of Labour productivity (VMP), so changes in wages and real work rewards should tend to be compatible. Also, General Labour market experience and job-specific experience contribute positively to individual wages and productivity.

\section{Previous studies}

- A study was carried by Ziapour identified and analysed Labour productivity components based on ACHIEVE Model, a case study on staff of Kermanshah University of Medical Sciences [10]. The study found that the seven factors; Environment, Performance, Assessment, Validity, Motivation, Organizational support, Clarity and Ability were effective factors in increasing Labour productivity. Evaluation and environment had the greatest impact on Labour productivity.

- George [11] presented a study about Labour productivity, concluded that the most important factors affecting Labour productivity included: ability, job clarity, job performance, evaluation, motivation and environmental factors.

- Developed a model for Labour productivity in which components; leadership, motivation, experience, creativity and innovation, education, competition and characteristics of the population were identified as the most important factors affecting productivity.

- Abdulbasit and Bataina [12], in their study on Jordon Labour market, aimed to measure women's productivity in Jordon Labour market, at the level of the economy as a whole as well as 
Citation: Abdulrahman HA (2017) Impact of Human Capital Input and Institutional Factors on Productivity of Female Staff in Princess Nourah bint Abdulrahman University (PNU). Bus Eco J 8: 324. doi: 10.4172/2151-6219.1000324

at sectorial level. The study showed that women's productivity came very low comparing with men's productivity in the economy as a whole about one third of men's productivity, and in the economic sectors with the exception of services sector.

- Labour productivity in Saudi Arabia, [13] is a study carried by World Bank for Ministry of Economy and Planning in Saudi Arabia. The study analysed productivity developments in the Kingdom of Saudi Arabia over the last quarter-century. The overall findings are that, despite large increases in output and value added productivity growth has been sluggish. The proximate cause of this is a product and Labour market structure in which output has expanded largely through:

o Employment of low-skilled expatriate Labour in low productivity activities such as wholesale and retail trade; community, social, and personal services and construction.

o Expansion of the government services sector, a low productivity sector but one which employ mostly Saudi nationals. Higher productivity sectors like manufacturing, communications and finance have not grown fast enough in employment and productivity terms to have a significant effect on overall trends.

\section{Methodology}

The study used a descriptive analysis model based on questionnaire it is called (ACHIEVE) model. This model is used by Ziapour [10] in their study titled (Identification and analysis of Labour productivity components based on ACHIEVE Model: Case study: staff of Kermanshah University of Medical Sciences). The ACHIEVE Model can help managers to determine difficulties in the performance; it consists of human input and institutional factors, affecting the productivity of staff, as follows:

1. Ability (Knowledge, skills, training and experience)

2. Clarity (perceived or imagined role)

3. Help (organizational Support)

4. Incentives (motivation or desire)

5. Evaluation (performance feedback)

6. Validity (valid and legal practice of employees)

7. Environment (environmental fit).

A random sample of (100) participant was selected from the staff population of Princess Norah University, it formed from two categories (educational and administrative) staff. A questionnaire was designed consisting of two sections, the first section was about personal information of participants. The second section consisted of (50) statements (predictors) represented the seven main variables of (ACHIEVE) Model. A five Likert Scale Model was used scaled starting from (1- strongly agree to 5- strongly disagree) for each statements of the ACHIEVE predictors.

Tools of SPSS statistical program were used for analysing data. The following Descriptive and inferential statistical analysis tools were used:

1. Frequencies of the sample indicators

2. Validity and reliability of the questionnaire

3. Mean and standard deviation for all predictors of the ACHIEVE model factors
4. One sample T-Test for all predictors of the ACHIEVE model factors

5. Multi correlation coefficient (R), and determinant factor of the regression analysis $\left(\mathrm{R}^{2}\right)$ are used to state the causal relation of the dependent variable (PNU female staff productivity) with the seven independent factors of (ACHIEVE model).

\section{Results and Discussion}

\section{Sample description}

A sample of (100) participants was selected randomly from the population of PNU academic and administrative staff. Table 1 shows the description of the sample in a form of numbers and frequencies.

The majority of the sample participants are female $98 \%$, this due to the sexual component of the university staff which is dominated by females from one side, and for the weak response of male to answer the questionnaire from the other side. The age distribution of the sample indicated that about $50 \%$ of the participants are of middle age category (31-40) years.

The Saudis represented $71 \%$ of the respondents, which is consistent with the university population, where Saudis are the majority of the teaching staff and whole of the administrative staff. The participants of the sample with academic occupations, constituted (47\%) followed by the administrative (40\%), while the academic administrative were just (13\%). The educational distribution of the sample participants showed that the highest percentage of the respondents were of Master degree, followed by those of $\mathrm{PhD}$ degree and most of them are academic staff, while the majority of the administrative staff are of Bachelor and Diploma degrees (Table 1).

One of the questions of the questionnaire is about the respondents' opinions on PNU female staff productivity, the answers are scaled into 5

\begin{tabular}{|c|c|c|c|}
\hline Variable & Classification & No. & Frequency $\%$ \\
\hline \multirow{3}{*}{ Sex } & Female & 98 & $98 \%$ \\
\hline & male & 2 & $2 \%$ \\
\hline & Total & 100 & $100 \%$ \\
\hline \multirow{3}{*}{ Nationality } & Saudi & 71 & $71 \%$ \\
\hline & Non-Saudi & 29 & $29 \%$ \\
\hline & Total & 100 & $100 \%$ \\
\hline \multirow{5}{*}{ Age } & $20-30$ & 14 & $14 \%$ \\
\hline & $31-40$ & 49 & $49 \%$ \\
\hline & $41-50$ & 23 & $23 \%$ \\
\hline & $50+$ & 14 & $14 \%$ \\
\hline & Total & 100 & $100 \%$ \\
\hline \multirow{5}{*}{ Occupation } & Academic & 47 & $47 \%$ \\
\hline & Administrative & 40 & $40 \%$ \\
\hline & Academic administrative & 13 & $13 \%$ \\
\hline & Total & 100 & $100 \%$ \\
\hline & secondary & 11 & $11 \%$ \\
\hline \multirow{5}{*}{ Education } & Diploma & 15 & $15 \%$ \\
\hline & Bachelor & 19 & $19 \%$ \\
\hline & Master & 35 & $35 \%$ \\
\hline & $\mathrm{PhD}$ & 20 & $20 \%$ \\
\hline & Total & 100 & $100 \%$ \\
\hline
\end{tabular}

Table 1: Sample indicators 
Citation: Abdulrahman HA (2017) Impact of Human Capital Input and Institutional Factors on Productivity of Female Staff in Princess Nourah bint Abdulrahman University (PNU). Bus Eco J 8: 324. doi: 10.4172/2151-6219.1000324

Page 4 of 6

scores (very high to very low). The results of this question indicated that $40 \%$ of the respondents believe that the PNU female staff productivity is high, $33 \%$ think it is medium, $17 \%$ is very high, while just $5 \%$ consider it is low and very low. This result denotes to the high level of productivity of PNU female staff according to staff points of view; hence the percentage of who consider it high and very high is about $57 \%$ which are more than half of the sample participants (Figure 1).

\section{Validity and reliability}

Face and Content Validity of the questionnaire was carried out through colleagues and experts review. Reliability factor of Cronbach's Alpha given by SPSS program was used indicated to (0.954) that means the reliability of the questionnaire statements is $95 \%$ which is a high degree of reliability referred to the standard (99\%).

\section{Mean and T-test analysis}

Each of the seven factors of (ACHIEVE) Model (Ability, Clarity, Help, Incentives, Evaluation, Validity and Environment), was represented by a number of predictors. Likert scale of five levels was used, began from strongly agree which took the symbol (1) to strongly disagree with symbol (5). Mean was found for all predictors of factors. A One sample T-Test was carried for each predictor of ACHIEVE model. T-value and two tailed significance level (0.05) was used to compare between the calculated mean of predictors and the assumed mean of the population (Table 2 ).

The Ability factor consisted of seven predictors concerning personal capabilities, education, training and attitude. Analysis showed that the mean of the respondent's opinions for most of the predictors was of degree (Agree). According to t-test analyses, all predictors of the Ability factor are statistically significant $(0.000)$ which is less than the (0.05). So we can accept the hypothesis, that Ability factor (personal skills and attitude of female employees) effect productivity of female staff in PNU (Table 3).

The clarity factor included eight predictors concerning job description, organizational system, commitment and knowledge of staff about their rights and duties and the organizational goals. Mean of all the statements was (2.6) of score (Agree). All statements of the clarity factor are statistically significant with a significance level $(0.000)$ which is less than (0.05), which indicates to accept that there is an effect of clarity factor on PNU female staff productivity and thus prove the study hypothesis (Table 4).

All predictors of Help factor including; regulation system, wages and other support patterns for employees got a mean of (Agree) degree, which reveals the positive opinions of the respondents on importance of this factor for PNU female staff productivity. T-Test analysis indicated that all statements of Help factor were statistically significant,

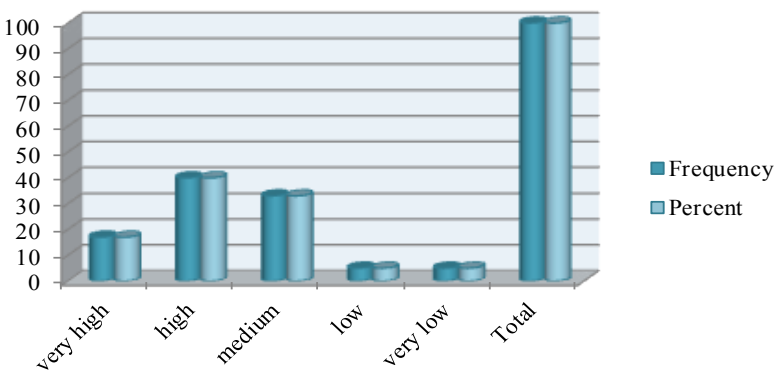

Figure 1: PNU female staff productivity.

\begin{tabular}{|l|c|c|c|c|}
\hline Statement & Mean & Score & T-value & Significance \\
\hline Knowledge of job tasks & 2.23 & Agree & 23.967 & 0 \\
\hline Computer skills & 2.33 & Agree & 26.231 & 0 \\
\hline English language & 3.21 & Neutral & 32.167 & 0 \\
\hline Personal skills of PNU employees & 2.56 & Agree & 29.483 & 0 \\
\hline Specialized training increase productivity & 2.08 & Agree & 24.85 & 0 \\
\hline Higher education increase productivity & 2.53 & Agree & 23.085 & 0 \\
\hline Positive attitude improve productivity & 2.3 & Agree & 23.731 & 0 \\
\hline
\end{tabular}

Table 2: One sample T-test for ability predictors.

\begin{tabular}{|l|c|c|c|c|}
\hline Statement & Mean & Score & T- value & Significance \\
\hline $\begin{array}{l}\text { Female employees know their job } \\
\text { description }\end{array}$ & 2.5 & Agree & 21.569 & 0 \\
\hline $\begin{array}{l}\text { Knowledge of organizational } \\
\text { instruction increase productivity }\end{array}$ & 2.6 & Agree & 27.896 & 0 \\
\hline $\begin{array}{l}\text { Knowledge of rights and duties } \\
\text { improve productivity }\end{array}$ & 2.71 & Agree & 24.555 & 0 \\
\hline Achieve their job in satisfied way & 2.34 & Agree & 26.63 & 0 \\
\hline $\begin{array}{l}\text { Knowledge of structural } \\
\text { organization of units }\end{array}$ & 2.5 & Agree & 22.997 & 0 \\
\hline $\begin{array}{l}\text { Knowledge of university and units } \\
\text { goals }\end{array}$ & 2.72 & Agree & 26.518 & 0 \\
\hline $\begin{array}{l}\text { Availability of easy communication } \\
\text { tools }\end{array}$ & 2.71 & Agree & 22.12 & 0 \\
\hline $\begin{array}{l}\text { Committed to hierarchy } \\
\text { organizational system }\end{array}$ & 2.55 & Agree & 24.79 & 0 \\
\hline
\end{tabular}

Table 3: One sample T-test for clarity predictors.

\begin{tabular}{|l|c|c|c|c|}
\hline Statement & Mean & Score & T-value & Significance \\
\hline $\begin{array}{l}\text { Regulation system assists in } \\
\text { increasing productivity }\end{array}$ & 2.53 & Agree & 25.24 & 0 \\
\hline $\begin{array}{l}\text { Wages and reward system } \\
\text { enhance productivity }\end{array}$ & 2.3 & Agree & 26.738 & 0 \\
\hline $\begin{array}{l}\text { Rich job content increase } \\
\text { productivity }\end{array}$ & 2.64 & Agree & 26.592 & 0 \\
\hline \begin{tabular}{l} 
Support of director \\
\hline $\begin{array}{l}\text { Employees with higher productivity } \\
\text { have more support of their } \\
\text { directors }\end{array}$
\end{tabular} & 2.77 & Agree & 24.54 & 0 \\
\hline $\begin{array}{l}\text { Employees enjoy high respect of } \\
\text { their directors }\end{array}$ & 2.7 & Agree & 26.81 & 0 \\
\hline
\end{tabular}

Table 4: One sample T-test for help predictors.

whereas, significance level for all statements is less than (0.05) denoting that Help factor effect the Productivity of PNU female staff and thus prove the validity of the hypothesis (Table 5 ).

Analysis showed that the calculated mean of incentives' predictors is (3.1) of neutral degree and which is more than (2.5), this indicates to low degree of agreement about the incentive factor. All Predictors of incentive factor including financial, moral incentives are existent affecting the PNU female staff productivity, as it is proved by the statistical significance of the statements $(0.000)$ which is less than (0.05), so we can accept the hypothesis of the study (Table 6).

Agree and strongly agree are the mean scores of the provision of objective and good evaluation system for the PNU staff. Mean of all evaluation predictors is (2.4) this denotes acceptance (Agree) of respondents for evaluation factor on PNU female productivity. T-Test analyses showed that evaluation factors affect the productivity of PNU female staff as the significant level of all predictors is $(0.000)$ which is less than the standard level of significance (0.05) (Table 7). 
Citation: Abdulrahman HA (2017) Impact of Human Capital Input and Institutional Factors on Productivity of Female Staff in Princess Nourah bint Abdulrahman University (PNU). Bus Eco J 8: 324. doi: 10.4172/2151-6219.1000324

Page 5 of 6

The respondents' answers concerning validity factor predictors: provision of delegation, freedom, performing duties and decision making authorities, are all of sore (Agree), with a mean of (2.7) for all statements reflecting agreement of respondents for existence of validity factor. Statistical significance of all validity predictors is $(0.000)$ less than (0.05), this means to accept there are freedom, participation in decision making and delegation of authorities of PNU female staff affecting their productivity (Table 8 ).

All predictors of the environment factor got calculated mean of score (Agree) and the mean for all statements is (2.6) showing positive opinion of the respondents towards the existence of good work environment. Environmental factor consisted of various predictors, all have got statistical significance level (0.000) indicating to the acceptance of the hypothesis that environment factor effect positively the productivity of PNU female staff.

\section{Correlation and regression analysis}

Multiple correlation coefficient (R) is found to show the relationship between the variable of (Productivity of PNU Female staff) and (the group of predictors for each factor of the ACIEVE model). The coefficient of determination $\left(\mathrm{R}^{2}\right)$ of the regression analysis is found to reveal the percent of variation in the dependent variable (PNU female staff productivity) explained by variation in the independent variables (group of predictors of each one of the ACHIEVE model factors) (Table 9).

The multi correlation coefficient, showed that there is strong positive relation between PNU female staff productivity, and the group predictors of Ability factor (0.71), followed by the positive multi correlation of Clarity predictors with PNU female staff productivity (0.6), while there is weak positive correlation (0.4) between PNU female staff productivity and predictors of Help. Predictors of environment have positive weak multi correlation coefficient (0.31) with PNU female staff productivity. Analysis indicated that the incentive, evaluation and

\begin{tabular}{|l|c|c|c|c|}
\hline Statement & Mean & Score & T- value & Significance \\
\hline $\begin{array}{l}\text { Existence of incentives for } \\
\text { employees increase their } \\
\text { productivity }\end{array}$ & 2.89 & Agree & 25.24 & 0 \\
\hline $\begin{array}{l}\text { There is high level of } \\
\text { incentives for the employees }\end{array}$ & 3.07 & Neutral & 26.738 & 0 \\
\hline $\begin{array}{l}\text { University provides financial } \\
\text { incentives }\end{array}$ & 3.31 & Neutral & 26.592 & 0 \\
\hline $\begin{array}{l}\text { University provides moral } \\
\text { incentives }\end{array}$ & 2.98 & Agree & 24.542 & 0 \\
\hline $\begin{array}{l}\text { There is objective system for } \\
\text { incentives }\end{array}$ & 3.16 & Neutral & 26.819 & 0 \\
\hline
\end{tabular}

Table 5: One sample T-test for incentive factor

\begin{tabular}{|l|c|c|c|c|}
\hline Statement & Mean & Score & T- value & Significance \\
\hline $\begin{array}{l}\text { Objective evaluation of } \\
\text { employees direct their } \\
\text { productivity to the right track }\end{array}$ & 2.16 & Agree & 22.472 & 0 \\
\hline $\begin{array}{l}\text { High evaluation of employee } \\
\text { raise their productivity }\end{array}$ & 1.89 & $\begin{array}{l}\text { Strongly } \\
\text { agree }\end{array}$ & 23.545 & 0 \\
\hline $\begin{array}{l}\text { Employees benefit of their } \\
\text { evaluation feedback }\end{array}$ & 2.3 & Agree & 25.747 & 0 \\
\hline $\begin{array}{l}\text { University is keen for high } \\
\text { productivity employees }\end{array}$ & 2.73 & Agree & 22,981 & 0 \\
\hline $\begin{array}{l}\text { Evaluation covers all aspects } \\
\text { relevant to employees } \\
\text { productivity }\end{array}$ & 2.82 & Agree & 27.156 & 0 \\
\hline
\end{tabular}

Table 6: One sample T-test for evaluation predictors.

\begin{tabular}{|l|c|l|c|c|}
\hline Statement & Mean & Score & T -value & Significance \\
\hline $\begin{array}{l}\text { Directors practice delegation of } \\
\text { authorities with their employees }\end{array}$ & 2.53 & Agree & 27.646 & 0 \\
\hline $\begin{array}{l}\text { Employees have freedom to } \\
\text { express their opinion }\end{array}$ & 2.72 & Agree & 26.471 & 0 \\
\hline $\begin{array}{l}\text { Employees enjoy freedom in } \\
\text { performing their duties }\end{array}$ & 2.76 & Agree & 26.155 & 0 \\
\hline $\begin{array}{l}\text { Employees are involved in } \\
\text { decision making }\end{array}$ & 2.8 & Agree & 25.432 & 0 \\
\hline
\end{tabular}

Table 7: One sample T-test for validity predictors.

\begin{tabular}{|l|c|c|c|c|}
\hline Statement & Mean & Score & T- value & Significance \\
\hline $\begin{array}{l}\text { There are good buildings, equipment } \\
\text { and supplies }\end{array}$ & 2.04 & Agree & 19.193 & 0 \\
\hline $\begin{array}{l}\text { Availability of information for } \\
\text { achieving tasks }\end{array}$ & 2.43 & Agree & 22.794 & 0 \\
\hline $\begin{array}{l}\text { There are goals and measurements } \\
\text { for performing job }\end{array}$ & 2.63 & Agree & 23.377 & 0 \\
\hline $\begin{array}{l}\text { Job tasks are well suited eth } \\
\text { employees abilities }\end{array}$ & 2.7 & Agree & 24.114 & 0 \\
\hline $\begin{array}{l}\text { There are effective methods for } \\
\text { accountability and monitoring }\end{array}$ & 2.75 & Agree & 24.114 & 0 \\
\hline $\begin{array}{l}\text { Employees enjoy good work relations } \\
\text { Employees are satisfied }\end{array}$ & 2.42 & Agree & 27.201 & 0 \\
\hline $\begin{array}{l}\text { Prevalence of teamwork and } \\
\text { cooperation between employees }\end{array}$ & 2.58 & Agree & 27.005 & 0 \\
\hline $\begin{array}{l}\text { There are good relations between } \\
\text { directors and employees }\end{array}$ & 2.51 & Agree & 24.608 & 0 \\
\hline
\end{tabular}

Table 8: One sample T-test for environmental predictors.

Factor

Predictors of Ability

\begin{tabular}{|c|c|c|c|c|}
\hline $\mathbf{D f}$ & $\mathbf{R}$ & $\mathbf{R}^{\mathbf{2}}$ & $\mathbf{F}$ & Significance \\
\hline 7 & 0.709 & 0.503 & 13.296 & 0 \\
\hline 8 & 0.603 & 0.363 & 6.49 & 0 \\
\hline 6 & 0.44 & 0.194 & 3.731 & 0.002 \\
\hline 5 & 0.192 & 0.037 & 0.721 & 0.61 \\
\hline 5 & 0.183 & 0.033 & 0.649 & 0.663 \\
\hline 4 & 0.099 & 0.01 & 0.237 & 0.917 \\
\hline 9 & 0.309 & 0.096 & 1.058 & 0.401 \\
\hline
\end{tabular}

Predictors of Clarity

Predictors of Help

Predictors of Incentives

Predictors of Evaluation

Predictors of Validity

Predictors of Environment

Table 9: Multiple correlation and regression of the model.

validity factors have very weak positive relation with productivity of female staff in PNU about $(0.2,0.2$, and 0.1$)$ consequently.

The coefficient of determination $\left(\mathrm{R}^{2}\right)$ implied that predictors of Ability have the highest level of explanation (50\%) for PNU female staff productivity compared to the rest of ACHIEVE model factors. This lead to the rejection of the hypothesis that environmental factor is the most effective factor for PNU female staff productivity. The Clarity predictors come in the second rank in describing the PNU female staff productivity (36\%). The three factors (Ability, Clarity and Help) have significant statistical level less than (0.05), this mean to accept the hypothesis that these factors affect PNU female staff productivity. About just (19\%) the predictors of Help have explained the PNU female staff productivity. Very low $\left(\mathrm{R}^{2}\right)$ are of predictors of Environment, incentives, Evaluation and validity $(9 \%, 4 \%, 3 \%, 1 \%)$ consequently and these factors are not statistically significant, more than (0.05).

\section{Conclusion and Recommendations}

The main results of this study can be summarized in the following:

- Majority of the respondents consider that PNU female staff productivity is high.

- Mean of human capital and organizational factors for PNU 
Citation: Abdulrahman HA (2017) Impact of Human Capital Input and Institutional Factors on Productivity of Female Staff in Princess Nourah bint Abdulrahman University (PNU). Bus Eco J 8: 324. doi: 10.4172/2151-6219.1000324

Page 6 of 6

female staff productivity is of score (Agree).

- T-Test analysis showed that all ACIEVE Model variables, (human capital and organizational factors) are statistically significant for PNU female staff productivity.

- According to multi correlation and regression analysis, Ability factor has the largest effect on PNU female staff productivity, followed by the Clarity and Help factors consequently.

- Analysis showed very low correlation and determination of PNU female staff productivity with the institutional factors; Environment, incentive, validity and evaluation.

Findings of this study are compatible with findings of (Ziapour [10] and George [11]) studies, which indicated to the effect of Ability and Organizational factors on Labour productivity. The present study findings differs with findings in that for Arash, Evaluation and Environment factors have the greatest impact on Labour productivity, while this study found that Ability, Clarity and help factors have the largest effect on Labour productivity for PNU female staff [10].

\section{According to the findings of study, the following recommendations are stated to boost female staff productivity in KSA:}

- More investments in human capital (skills and knowledge) to keep high female staff abilities and thus productivity.

- Promoting work environment, evaluation and incentive systems of the organization.

- Developing clarity of organization regulations for playing more vital role.

- Strong support of the organization administration for female staff is required to enhance their productivity.

\section{References}

1. Saranac L (2000) Human Capital, the profit Lever of Knowledge Economy AMA Books.

2. Guido S, Turunen J (2009) Changes in Human Capital: Implication for Productivity Growth in the Euro Area. OCED Publications.

3. Meera A, Patrick R (2016) Capacity and Capability Building for National HRD: A multi-Level Conceptual Framework. Human Resources Development Review.

4. Kamilla H, Sorjerbo H (2009) Labor Productivity based on Integrated Labor Accounts; Does it make any difference? In OCED. OCED publications.

5. Abdalziz A (2013) Commercial Openness policies and its role in improving productivity in Algerian organizations as a competitive indication. Journal of Organizational Performance.

6. Mohamed R (2015) Organizational Behavior (Individual and Group Behavior in Organizations). Al Mutanabi Publications.

7. ILO Report (2008) Skills for Improving Productivity, Labor Growth and Development.

8. OCED Manual (2001) Measuring of Aggregate and Industry level Productivity Growth.

9. Emsina AA (2014), Labor Productivity, Economic Growth and Global Competitiveness in Post -Crisis Period, Economics and Management.

10. Ziapour A, Khatony A, Kianipour N, Jafary F (2014), Identification and Analysis of labor Productivity Components based on achieve Model(case study :staff of Kermanshah University of Medical Science), Global Journal of Health Science 7: $315-321$

11. George B (2013) Labor Economics. Mac-grow Hill publications.

12. Abdulbasit O, Bataina A (2014) Enhancing Women Productivity and women Labor force Participation for Investment in Jordanian women Development. HRD Arab World Conference, Morocco.

13. Labor Productivity in Saudi Arabia 1987-2011 (2013), A Study prepared by the World Bank for Ministry for Economy \& Planning. 